\title{
Contributions of transcriptional and post-transcriptional mechanisms to the regulation of c-myc expression in mouse erythroleukemia cells
}

\author{
Alain Nepveu, ${ }^{1}$ Kenneth B. Marcu, ${ }^{1}$ Arthur I. Skoultchi, ${ }^{3}$ and Herbert M. Lachman ${ }^{2}$ \\ ${ }^{1}$ Department of Biochemistry, State University of New York, Stony Brook, New York 11794-5215; ${ }^{2}$ Department of Medicine, \\ Division of Hematology; ${ }^{3}$ Department of Cell Biology, Albert Einstein College of Medicine, Bronx, New York 10461 USA
}

\begin{abstract}
Chemically induced differentiation of mouse erythroleukemia (MEL) cells leads to complex changes in c-myc mRNA levels. Within 1-2 hr after the addition of the inducer hexamethylene bisacetamide (HMBA), c-myc mRNA levels decrease 10- to 20-fold and remain low until 12-24 hr, at which time the mRNA reaccumulates to its original level. Thereafter as the cells undergo terminal differentiation, c-myc mRNA again declines to a low level. We have investigated the regulation of these changes by measuring c-myc gene transcription and mRNA turnover. We find that the early rapid decline in c-myc mRNA is due to an increase in the block to elongation of transcription within the c-myc first exon. Effective c-myc transcription is then restored after $2 \mathrm{hr}$ of HMBA treatment to the level present in uninduced cells and is maintained throughout the remainder of the differentiation program. These results demonstrate that, except for the rapid decline in c-myc mRNA immediately following inducer treatment, all subsequent regulation of message levels occurs through posttranscriptional mechanisms. Studies of $c-m y c$ mRNA turnover suggest that some post-transcriptional regulation is nuclear.
\end{abstract}

[Key Words: Mouse erythroleukemia cells; c-myc RNA levels; transcriptional mechanisms]

Received July 2, 1987; revised version accepted September 18, 1987.

MEL cells are erythroid precursor cells that are blocked at an early stage of erythroid differentiation (Marks and Rifkind 1978). Upon treatment with one of a variety of chemical inducing agents such as dimethylsulfoxide (DMSO) or hexamethylene bisacetamide (HMBA), MEL cell lines reinitiate a program of erythroid differentiation culminating in extensive hemoglobin synthesis and terminal cell division (Reuben et al. 1976; Marks and Rifkind 1978). Following a 12 to 18 -hr latency period, there is an increasing percentage of cells that are gradually recruited into a commitment program (Gusella et al. 1976). Once committed, cells are capable of terminal differentiation in the absence of further exposure to inducer. We have previously shown that the level of c-myc mRNA is drastically altered during this latent period (Lachman and Skoultchi 1984). First, there is a 10 -fold decrease in c-myc mRNAs, within 1-2 $\mathrm{hr}$ following the addition of inducers of differentiation. The level of c-myc transcripts remains relatively low until 12-24 hr of inducer treatment when c-myc mRNAs reaccumulate transiently. The early decline in c-myc mRNA and its subsequent reexpression just prior to commitment originally led us to suggest that both events are important for terminal differentiation (Lachman and Skoultchi 1984). The effects of exogenous myc genes on MEL cell differentiation support this hypothesis /Coppola and Cole
1986; Dmitrovsky et al. 1986; Lachman et al. 1986; Prochownik and Kukowska 1986).

Transcriptional and post-transcriptional mechanisms have both been shown to modulate c-myc mRNA levels in a variety of biological systems (for review, see Marcu 1987). In some situations, one type of mechanism has been ascribed the main, if not the sole, role in modulating the levels of c-myc mRNAs. Down-regulation of c-myc expression in differentiating HL60 human promyelocytic leukemia cells (Bentley and Groudine 1986; Eick and Bornkamm 1986) and in Abelson murine leukemia virus (Ab-MLV)-transformed fibroblast lines (Nepveu and Marcu 1986) has been shown to result largely from a block in transcriptional elongation within the c-myc first exon. In addition, antisense transcription occurs in multiple places within the c-myc locus, suggesting that this phenomenon may also contribute to this gene's regulation (Nepveu and Marcu 1986).

In this report, we have examined the relative contributions of sense transcription initiation, transcriptional block, antisense transcription, and post-transcriptional mechanisms for the regulation of the c-myc gene in inducer-treated MEL cells. We find that the regulation of c-myc mRNA levels in differentiating MEL cells is quite complex. The early rapid reduction in c-myc mRNAs is due to enhanced transcriptional block while subsequent 
changes in the mRNA level are due to post-transcriptional mechanisms. Remarkably, we find that anti-sense transcription and the initiation of c-myc sense transcription are invariant throughout MEL cell differentiation.

\section{Results}

\section{Regulation of c-myc sense transcription}

MEL cells were induced to differentiate in vitro by cultivating them in the presence of HMBA. Nuclei and total cellular RNA were prepared at various times during and after the latent period. RNAs were separated by $0.9 \%$ agarose-formaldehyde gel electrophoresis, transferred to nitrocellulose filters, and probed with a ${ }^{32} \mathrm{P}$-labeled c-myc DNA fragment. We observe about a 20 -fold decrease in c-myc mRNA $1 \mathrm{hr}$ following the addition of HMBA (see Figs. 1A and 6B). The level of c-myc RNA remains low until $16 \mathrm{hr}$, when it transiently reaccumulates. Thereafter, the level of c-myc mRNA decreases again as the cells differentiate terminally. Although only normal-size c-myc mRNAs were detected by Northern analysis, we performed S1 nuclease mapping analysis to determine if any initiation of transcription occurred within the c-myc first intron, as it was previously described (Ray et al. 1987). We used a uniformly labeled probe derived from a normal c-myc cDNA containing sequences from the $3^{\prime}$ end of exon 1 and the $5^{\prime}$ end of exon 2 (Fig. 1B). Two exposures of the same gel are presented. We observe a major band of 298 nucleotides corresponding to the sum of the exon 1 and exon 2 sequences present in the probe. This band must be generated by transcripts initiated at the normal start sites P1 and P2 (Yang et al. 1985; J. Yang and K. Marcu, unpubl.). Densitometric scanning of the film indicates that these transcripts account for $\sim 90 \%$ of all c-myc mRNAs present in MEL cells. On the longest exposure, we also detect some minor bands, one of which (137 nucleotides) corresponds to the size of the exon 2 sequences present in the probe. This band is probably generated by transcripts initiated within the c-myc first intron. These transcripts represent $\sim 5 \%$ of all c-myc mRNAs. The origin of the other more minor bands cannot be identified unambiguously.

To determine whether these changes in c-myc mRNA levels are due to fluctuations in transcription rate, we performed nuclear run-on transcription assays using single-stranded DNA probes whose locations are shown in Figure 2B. To determine the rate of sense transcription, we used c-myc probes A and B (see Fig. 2B). Probe A provides an estimation of the initiation rate, while $B$ measures the rate of transcription $3^{\prime}$ of exon 1 , downstream of the region in which the transcriptional block has been mapped (Nepveu and Marcu 1986; Mechti et al. 1986; Nepveu et al. 1987). The apparent levels of transcription detected throughout the gene would depend on the uridine compositions of the region covered by each DNA segment and these are provided in the Figure 2 legend.

The transcription data are presented in Figures 2 /early time points), 3 , and 4 (intermediate and late time
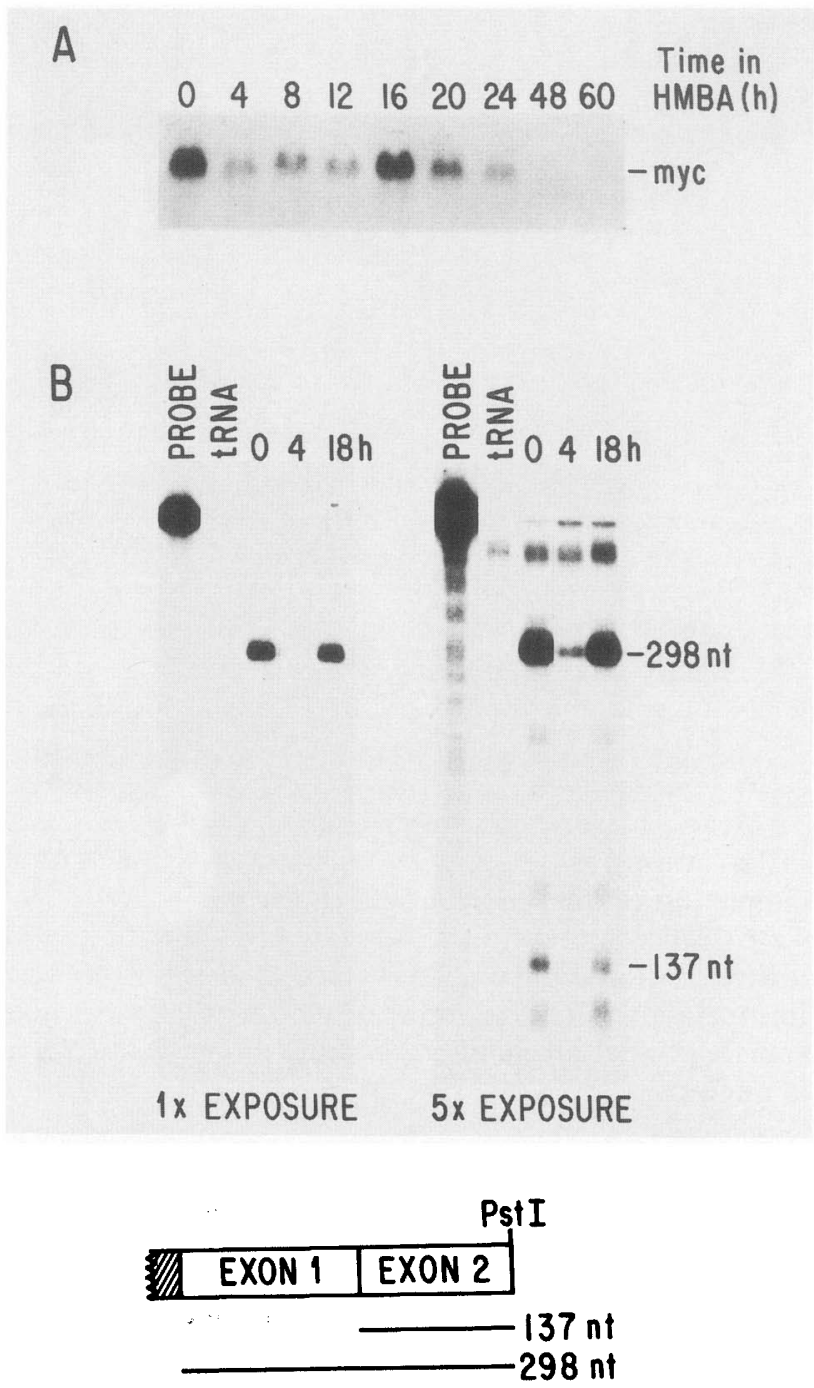

Figure 1. Changes in c-myc mRNA levels in MEL cells during HMBA treatment. Cells in logarithmic growth were treated with $5 \mathrm{mM}$ HMBA and total cellular RNA was extracted at the times indicated in the figure. $(A)$ Northern blot analysis. RNA was fractionated by electrophoresis through $0.9 \%$ agarose-formaldehyde gels and transferred to nitrocellulose filters. The filters were probed with a $1.36-\mathrm{kb}{ }^{32} \mathrm{P}$-labeled Xho fragment containing the mouse c-myc coding exons derived from the pMc-myc54 cDNA clone (Stanton et al. 1983, 1984). (B) S1 nuclease analysis. Samples $(30 \mu \mathrm{g})$ of total cellular RNA were hybridized to a uniformly labeled single-stranded DNA probe, exhaustively digested with $\mathrm{S} 1$ nuclease, and then analyzed on a 7 M urea polyacrylamide gel. The probe was derived from a c-myc cDNA and contained 161 nucleotides from the $3^{\prime}$ end of exon 1 and 137 nucleotides from the $5^{\prime}$ end of exon 2 ; the hatched area of the map represents $10 \mathrm{bp}$ of $C \gamma_{2 \mathrm{a}}$ switch region sequence. The location of $\mathrm{S} 1$ protected bands corresponding to c-myc mRNAs initiated within exon 1 (298 nt) and intron 1 (137 nt) are indicated. The panel on the right is a fourfold exposure of the left panel.

points). The early time points $(0-2 \mathrm{hr}$ ) correspond to the early rapid reduction in c-myc mRNA levels; the intermediate and late times $(2-60 \mathrm{hr})$ are when c-myc mRNAs remain at a low level, reaccumulate transiently, 
Figure 2. Nuclear run-on transcription assay of HMBA-treated MEL cells: early times post-HMBA. MEL cells in logarithmic growth were treated with $5 \mathrm{mM} \mathrm{HMBA}$ and nuclei were isolated at the indicated times. Nuclear run-on transcription assays were performed and ${ }^{32}$ P-labeled RNAs were hybridized to c-myc M13 ssDNAs and GAPDH dsDNA immobilized on nitrocellulose. Presented below is a map of the mouse $c-m y c$ gene. Only the restriction sites used in the cloning of the c-myc DNA fragments are shown with their boundaries indicated by arrows. Probes complementary to sense and antisense transcripts are shown above and below the map, respectively. The intensity of the hybridization signal obtained with each probe depends on the number of uridine residues present in the RNA that binds to it. The numbers of uridine residues present in the region covered by each probe are as follows: $\mathrm{A}(94), \mathrm{B}(585), \mathrm{C}(117), \mathrm{D}(158), \mathrm{E}(82), \mathrm{F}(113), \mathrm{G}(324)$. The GAPDH probe is the Pst ${ }^{\star}$ fragment of the rat glyceraldehyde-3-phosphate-dehydrogenase cDNA clone, pRGAPDH13 (Piechaczyk et al. 1984).
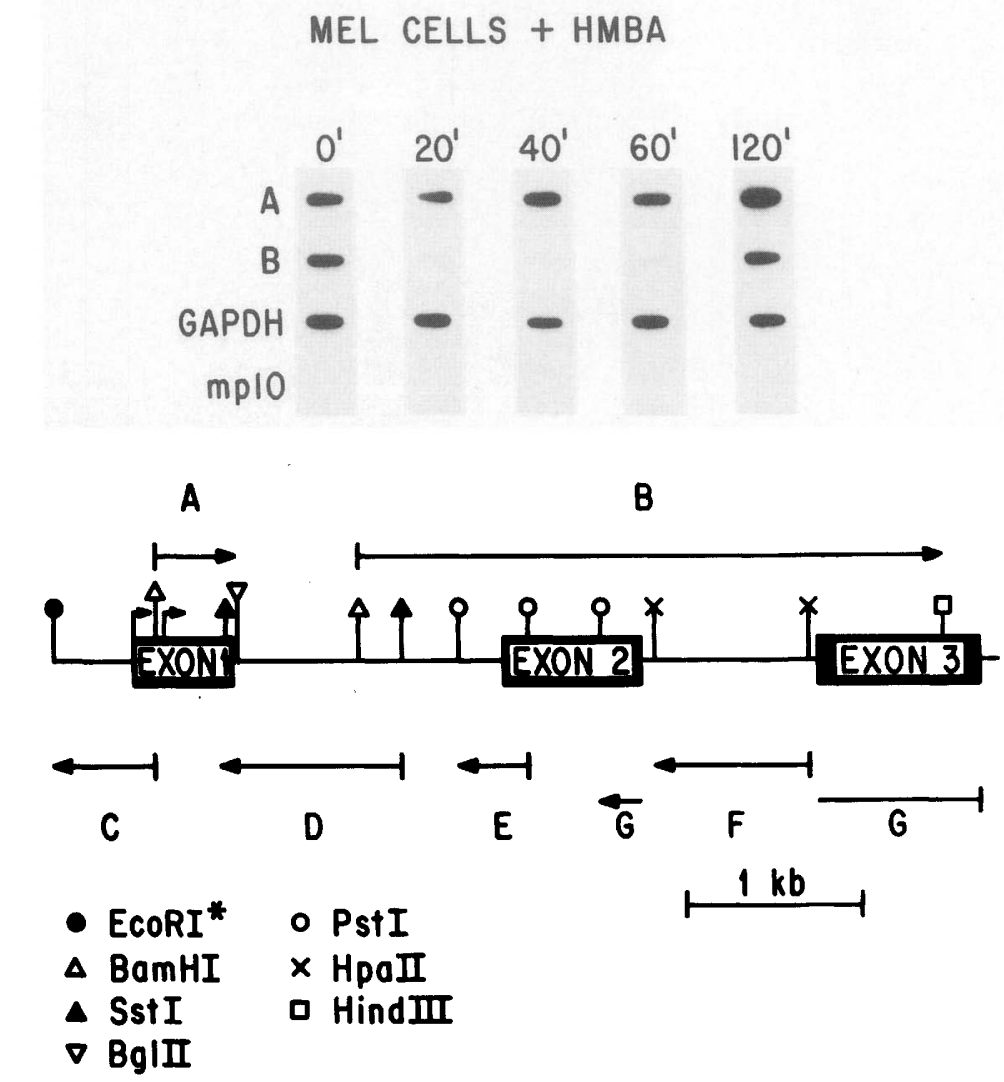

and finally drop to a very low level. In uninduced MEL cells ( $0 \mathrm{hr}$ time point in Figs. 2, 3, and 4), the signal from probe $A$ is of equal or slightly higher (twofold) intensity than that of probe $B$. The region covered by probe $A$ contains about six times less uridine residues than that of probe $B$. Therefore, when the signals from probes $A$ and $B$ are of similar intensity (Figs. 2 and 4), it means that the rate of transcription is about sixfold higher in the region of probe $A$. This difference is sometimes greater as is seen in Figure 3. These data indicate that a block to elongation of transcription occurs in proliferating MEL cells as it was described in other mouse cell lines (Nepveu and Marcu 1986; Mechti et al. 1986; Nepveu et al. 1987). Densitometric scanning of the signals from probes A and B reveals that in proliferating MEL cells, between $5 \%$ and $15 \%$ of the transcriptional complexes can progress to the coding region of the gene. The site of the transcriptional block has been mapped within the $3^{\prime}$ part of the first exon in several mouse cell lines as well as in transfected cell populations (Nepveu and Marcu 1986; Mechti et al. 1986; Nepveu et al. 1987; Nepveu et al., in prep.). We assume that the transcriptional block occurs in the same position in MEL cells. It is not yet known if this block results from a transient arrest in the progression of the transcriptional complexes /"intragenic pausing"| or from premature termination with the release of the polymerase from the template.

In Figure 2, transcription detected with probe $B$ is found to decrease at 20,40 , and $60 \mathrm{~min}$ after the start of HMBA treatment, whereas the probe A signals remain constant. This indicates that the transcriptional block is accentuated very early upon HMBA treatment and must contribute to the decrease in c-myc mRNA levels that are seen in Figure 1A. However after $2 \mathrm{hr}$ the signal from probe B regains its original intensity (also see Fig. 2), while the steady-state levels of cytoplasmic c-myc RNAs still remain very low. Therefore, these results suggest that post-transcriptional events are crucial for maintaining the very low level of $c-m y c$ mRNAs in this early phase of the latent period.

No major variation in sense transcription rates is discernible between 2 and $20 \mathrm{hr}$ after the start of HMBA treatment (see Figs. 2-4). The differences observed are generally within the normal range of variations between experiments. However, we reproducibly observe a slightly increased signal from probe A at $2 \mathrm{hr}$ (see Figs. 2 and 3 ), suggesting that the rate of initiation might be enhanced at that time. We note that this transient activation in exon 1 transcription coincides with, and therefore might contribute in part to, the transient augmentation in the rate of transcription downstream across the $B$ region. We also observe a twofold increase in the probe $B$ signal at $20 \mathrm{hr}$ (Fig. 4). This may contribute to the restoration in c-myc mRNA levels, although the timing and extent of this later transcriptional activation do not precisely correspond to those of the increase in cytoplasmic myc transcripts. The fact that there are no major changes in the rates of sense transcription between 2 and $20 \mathrm{hr}$ implies that transcription plays only a minor role, if any, in the upregulation of $c-m y c$ mRNA level in the 


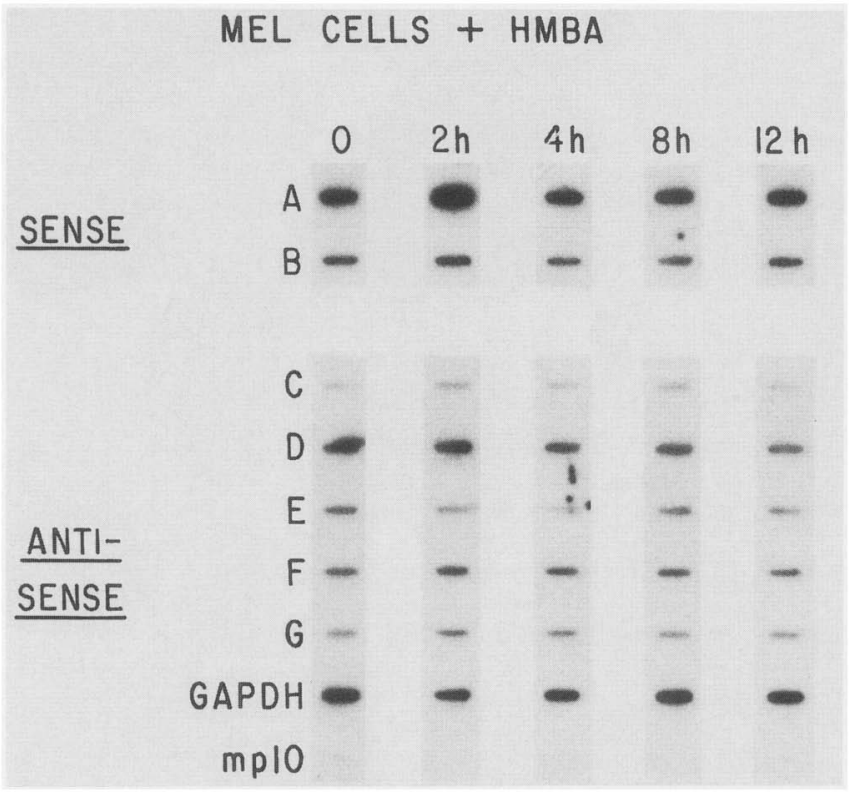

Figure 3. Nuclear run-on transcription assay of HMBA-treated cells: intermediate times post-HMBA. MEL cells in logarithmic growth were treated with $5 \mathrm{mM} \mathrm{HMBA}$. At the indicated times, nuclei were isolated and run-on transcription assays were performed. The details of the experiment are given in the Fig. 2 legend.

later phase of the commitment period. The levels of c-myc transcription at 48 and $60 \mathrm{hr}$ after the start of HMBA treatment are shown in Figure 4. By this time c-myc mRNAs have diminished to a final very low level and the cells have started to synthesize $\alpha$ - and $\beta$-globins. We see that the signals from probes $A$ and $B$ are of equal or greater intensity than in the uninduced cells. This indicates that in terminally differentiated MEL cells, the downregulation of $c-m y c$ expression occurs at the posttranscriptional level.

\section{Antisense c-myc transcription is unaffected by differentiation induction}

As previously described, three portions of the c-myc locus show relatively high levels of antisense transcrip- tion: the region upstream of the gene (probe C), the first intron (probes D and E), and the $3^{\prime}$ half of the gene (probes $F$ and $G$ ). The results presented in Figure 3 indicate that there is no significant change in the rate of antisense transcription within the c-myc gene during differentiation induction. Variations within intron 1 have been seen in some experiments (data not shown). However, since such fluctuations are not observed reproducibly, we conclude that, at least in MEL cells induced to differentiate, fluctuation in the levels of c-myc mRNAs cannot be correlated with any change in antisense transcription.

\section{Measurements of $c$-myc mRNA turnover in uninduced and differentiating $M E L$ cells}

The data shown in Figures 2 and 3 demonstrate that transcription downstream of the $c-m y c$ first exon is restored to its original level $2 \mathrm{hr}$ after HMBA treatment while the mRNA level remains drastically reduced, suggesting that post-transcriptional events are involved in the maintenance of the low c-myc mRNA levels. To determine if c-myc mRNA stability is altered upon MEL cell differentiation, we measured the half-life $\left(t_{1 / 2}\right)$ in uninduced and inducer-treated cells using an actinomycin D chase protocol. Although the accuracy of mRNA turnover measurements made in actinomycin $\mathrm{D}$ for longerlived mRNAs is uncertain, prëvious determinations of c-myc mRNA $t_{1 / 2}$ using actinomycin D and approach to steady-state protocols have been comparable (Piechaczyk et al. 1985). This is likely due to the very short $t_{1 / 2}$ of c-myc mRNA. Uninduced MEL cells were incubated with $5 \mu \mathrm{g} / \mathrm{ml}$ actinomycin $\mathrm{D}$ and total cellular RNA was extracted every $20 \mathrm{~min}$ for $2 \mathrm{hr}$. Northern blot filters of total cellular RNAs were hybridized with $\alpha_{-}{ }^{32} \mathrm{P}-\mathrm{labeled} \mathrm{c}-\mathrm{myc}$ and histone H3 DNA probes. We used the $\mathrm{H} 3$ gene as a control for the accuracy of actinomycin $\mathrm{D}$ half-life determination because we previously measured the turnover of H3 RNA in MEL cells using a [ ${ }^{3} \mathrm{H}$ ]uridine pulse-chase protocol (Alterman et al. 1984). As shown in Figure $5 \mathrm{~A}$, actinomycin $\mathrm{D}$ treatment results in a linear decay in c-myc mRNAs with $t_{1 / 2}$ of approximately $13 \mathrm{~min}$. This value agrees well with pre-

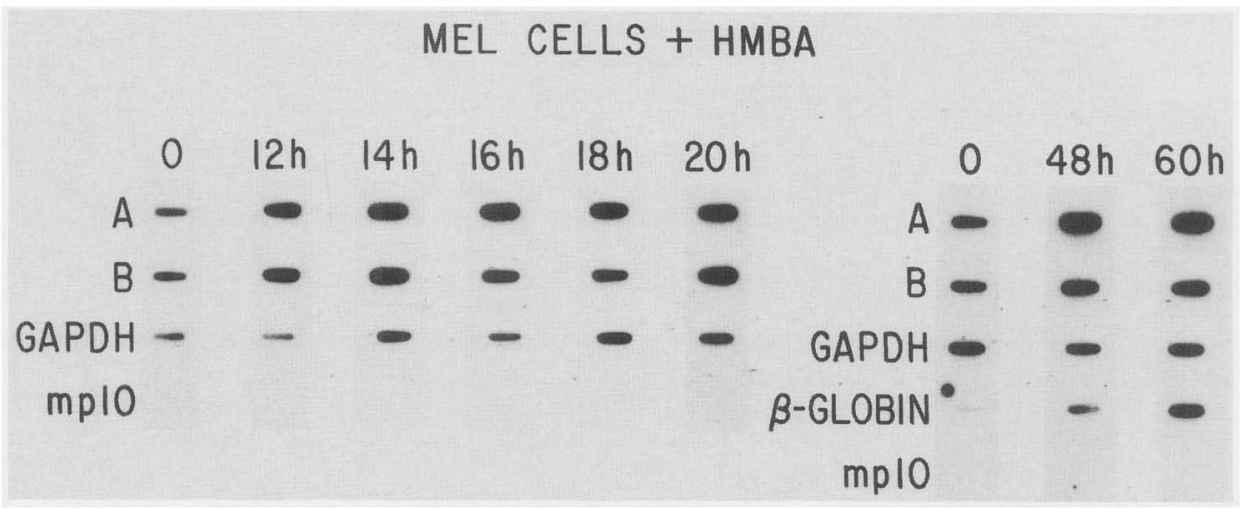

Figure 4. Nuclear run-on transcription assay of HMBA-treated cells: intermediate and late times post-HMBA. MEL cells in logarithmic growth were treated with $5 \mathrm{~mm}$ HMBA. At the indicated times, nuclei were isolated and run-on transcription assays were performed. The details of the experiment are given in the Fig. 2 legend. 
Nepveu et al.

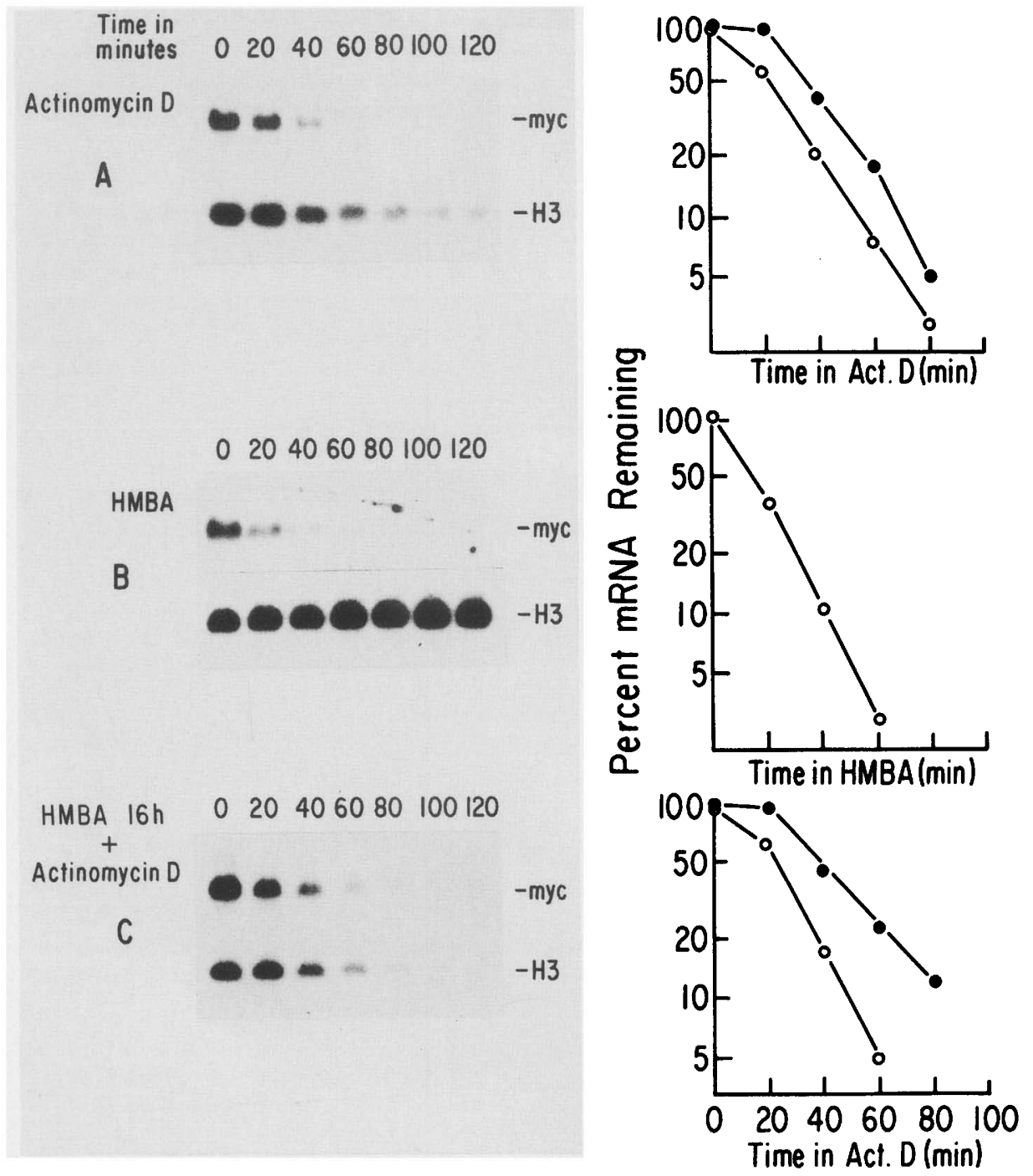

Figure 5. Turnover of c-myc mRNAs. Uninduced MEL cells were treated with $5 \mu \mathrm{g} / \mathrm{ml}$ actinomycin D $(A)$ or $5 \mathrm{mM}$ HMBA $(B)$ and total cellular RNA was extracted every $20 \mathrm{~min}$ for $2 \mathrm{hr}$. In the experiment shown in $C$, the cells were first treated with $5 \mathrm{mM}$ HMBA for $16 \mathrm{hr}$ and then $5 \mu \mathrm{g} / \mathrm{ml}$ actinomycin D was added. Total cellular RNA was extracted every $20 \mathrm{~min}$ for $2 \mathrm{hr}$. Levels of c-myc mRNAs were measured by Northern blot filter hybridization as described in Fig. 1 and the filters were rehybridized to a mouse H3 histone gene probe, pRAH3-2 (Alterman et al. 1984). Autoradiograms exposed within the film's linear response range were scanned with a Cambridge Quantimet 920 Image Analysis System. The percentages of myc $(O)$ and $\mathrm{H} 3$ histone $(O)$ mRNAs remaining after HMBA or actinomycin $\mathrm{D}$ treatment were calculated by dividing the densitometric signal at each time by the starting value, and then multiplying by 100 .

viously published c-myc mRNA half-life determinations and indicates that $\mathrm{c}-\mathrm{myc} \mathrm{mRNA}$ is also quite unstable in uninduced MEL cells (Dani et al. 1984; Piechaczyk et al. 1985). We also plotted the densitometric analysis of the H3 hybridizing signals and obtained a $t_{1 / 2}$ of $19 \mathrm{~min}$. This agrees reasonably well with the 25 -min $t_{1 / 2}$ of the relatively unstable $\mathrm{H} 3$ RNA pool previously measured by pulse-chase labeling given the variations in cellular physiology with these different protocols (Alterman et al. 1984).

We next compared the decay in c-myc mRNA following actinomycin $\mathrm{D}$ chase with the rate that $\mathrm{c}-m y c$ mRNA decays during HMBA treatment. MEL cells were treated with $5 \mathrm{~mm}$ HMBA and total cellular RNA was extracted every $20 \mathrm{~min}$ for $2 \mathrm{hr}$. The relative levels of c-myc and $\mathrm{H} 3$ mRNAs seen in Figure 5B were determined as described above. In contrast to actinomycin D treatment, the addition of HMBA does not significantly affect H3 mRNA levels, consistent with our previously published results (Lachman and Skoultchi 1984). However, similar to actinomycin D treatment, HMBA induces a rapid decrease in c-myc mRNA levels. As seen in the densitometric analysis in Figure $2 B$, the decay of c-myc mRNA occurs with an apparent $t_{1 / 2}$ of $10 \mathrm{~min}$. The similarities in the rate of decay of c-myc mRNA following HMBA or actinomycin D treatment suggest that the early HMBA-induced decline in c-myc mRNA is not due to its increased instability. These data are con- 
sistent with the conclusions derived from the nuclear run on assays indicating that enhanced transcriptional blockage is the major cause for the early decline in c-myc mRNA levels.

We also considered the possibility that c-myc mRNA stability may be a factor that results in the transient reaccumulation of c-myc mRNA during HMBA treatment since effective transcription was fairly stable during this period. We treated MEL cells with HMBA for $16 \mathrm{hr}$, a period of time sufficient to allow c-myc levels to decrease and then reaccumulate. Cells were then treated with actinomycin D. Total cellular RNAs were extracted every $20 \mathrm{~min}$ for $2 \mathrm{hr}$, and c-myc and H3 mRNAs were analyzed as described above (see Fig. 5B). The halflives of c-myc and $\mathrm{H} 3$ and mRNAs are 13 and $20 \mathrm{~min}$, respectively (see Fig. $5 \mathrm{C}$ ), which are similar to those found in uninduced cells. Thus, we find that the c-myc mRNA half-life is no different in uninduced and $16-\mathrm{hr}$ HMBA-treated cells, and the rate of c-myc transcription is constant during these periods, except for a transient release from transcriptional block. Taken together these results suggest that nuclear post-transcriptional events such as RNA processing and/or transport may play an important role in c-myc mRNA changes in response to HMBA treatment.

\section{Discussion}

In this report we have studied the molecular mechanisms governing the rapid changes in c-myc mRNA that occur when MEL cells are treated with HMBA, a differentiation inducer. First, we measured the relative rate of c-myc transcription by an in vitro nuclear run on transcription assay in which we used single-stranded probes from various portions of the $\mathrm{c}-m y c$ gene. We find that, in undifferentiated MEL cells, a block to elongation of transcription occurs near the boundary of c-myc exon 1 and intron 1, similar to what has been seen in a variety of normal and transformed murine cells (Nepveu and Marcu 1986). Within 20 min following the addition of HMBA, the transcriptional block is accentuated, resulting in a reduced rate of transcription downstream of the first exon. Therefore, increased transcriptional blockage is primarily responsible for the rapid decrease in c-myc mRNAs in HMBA-treated MEL cells. A similar phenomenon has been observed in differentiating HL60 cells (Bentley and Groudine 1986; Eick and Bornkamm 1986). Increased blockage was also reported recently in MEL cells treated with DMSO for $3 \mathrm{hr}$ (Mechti et al. 1986). However, our time course analysis reveals that by $2 \mathrm{hr}$ of HMBA treatment the degree of blockage returned to its original level and the rate of transcription throughout the gene is equal to that found in uninduced cells; yet c-myc mRNA levels remain decreased. These data indicate that the early decrease in c-myc mRNA that occurs in inducer-treated MEL cells is due to a transient decrease in effective c-myc gene transcription; but the maintenance of the decreased levels of the mRNA, in the first $12 \mathrm{hr}$ of HMBA treatment, is effected posttranscriptionally. We also measured c-myc transcription between 12 and $20 \mathrm{hr}$ of HMBA treatment during which c-myc mRNA reaccumulates. We find that during most of this time period, c-myc transcription is relatively unchanged. It would appear that post-transcriptional regulation is the major mechanism that accounts for c-myc reexpression. At 48 and $60 \mathrm{hr}$, when the amounts of c-myc mRNAs have fallen again to a very low level, the rate of transcription is equal to or greater than that found in uninduced MEL cells. We conclude that posttranscriptional events are also responsible for the final downregulation in c-myc expression. We also found that antisense transcription does not vary when changes occur in the steady-state levels of c-myc mRNAs. Thus, it appears that antisense transcription is constitutive in MEL cells.

Post-transcriptional events play a very significant role in the regulation of $c-m y c$ mRNA levels in MEL cells. The maintenance of the 10- to 20-fold decrease in the mRNA following HMBA treatment, its subsequent 10fold reaccumulation, as well as its final downregulation, all occur in the absence of major changes in c-myc transcription. Therefore, we examined the potential role of $c-m y c$ mRNA stability in these changes. Actinomycin D chase experiments indicate that c-myc mRNA is unstable in uninduced MEL cells with a $t_{1 / 2}$ of approximately $13 \mathrm{~min}$, similar to that found in other cell lines. Following the addition of HMBA, c-myc mRNA levels decay with an apparent $t_{1 / 2}$ of approximately $10 \mathrm{~min}$. This value probably closely approximates the actual c-myc mRNA half-life in HMBA, since effective c-myc transcription, while detected, is very low at this time. This is supported by our finding that treatment of MEL cells simultaneously with actinomycin D and HMBA does not result in a more rapid disappearance of c-myc mRNAs (H. Lachman, unpubl.). At $16 \mathrm{hr}$ of HMBA treatment, the half-life of c-myc mRNA is similar to that found in uninduced MEL cells. Even though the low level of c-myc mRNA between 2 and $16 \mathrm{hr}$ of HMBAtreatment has precluded our ability to measure its turnover, the similarities of c-myc mRNA half-lives in uninduced cells, in those treated briefly in HMBA, and in 16-hr HMBA-treated cells suggests that these mRNA levels are modulated by nuclear post-transcriptional processes such as RNA maturation and/or transport.

Levels of c-myc mRNAs are regulated post-transcriptionally in a variety of cell lines. For example, the decrease in c-myc mRNA in differentiating F9 teratocarcinoma cells is thought to be post-transcriptional (Dean et al. 1986; Dony et al. 1985; Nepveu et al. 1987). Posttranscriptional mechanisms have also been invoked to explain the rapid changes in cytoplasmic myc RNAs in an anti- $\mu$-treated murine B lymphoma line (Levine et al. 1986). Similarly, Daudi cells treated with $\beta$-interferon exhibit a large decrease in c-myc mRNA that was attributed to a further decrease in the degradation rate of the mRNA (Dani et al. 1985), though this point remains controversial. While this report was being prepared, two papers dealing with the regulation of $c-m y c$ mRNA in MEL cells appeared (Mechti et al. 1986; Ramsey et al. 1986). In agreement with our results, Ramsey et al. 
found that c-myc transcription was decreased $1 \mathrm{hr}$ after the addition of HMBA and went up after 2 and $4 \mathrm{hr}$, although not to the level found at the zero time point. However, the fact that they used a double-stranded DNA probe from exon 2 precluded their ability to determine if transcriptional regulation occurred at the level of initiation or elongation. In disagreement with us, they did not observe a decrease in c-myc transcription as early as we did. We see this decrease as early as $20 \mathrm{~min}$ after addition of HMBA but they did not see it in their 30 -min time point. More importantly, at $60 \mathrm{hr}$, they find that c-myc mRNAs were at levels comparable to that seen in the uninduced MEL cells whereas we see very low levels of c-myc mRNAs at the same time point. Since our two groups apparently use the same cell line and the same inducer, these discrepancies cannot be easily reconciled. It is possible that these MEL cell lines have evolved differently and their c-myc expression does not follow the same time course upon HMBA treatment. Alternatively, variations in the feeding and/or inducer protocols may account for these differences. Mechti et al. recently reported that following treatment of MEL cells with DMSO, c-myc mRNA becomes more unstable (Mechti et al. 1986). In contrast, our results indicate that changes in c-myc stability at early times are not substantial enough to cause the dramatic changes in c-myc mRNA levels. Conceivably, differences in c-myc mRNA stability could exist between different MEL cell lines. They also detect an increase in transcriptional block $3 \mathrm{hr}$ following the addition of DMSO, similar to our 0- to 2-hr transcription results with HMBA. However, Mechti et al. neglected to measure c-myc transcription at frequent intervals early after DMSO treatment and also did not analyze c-myc expression in the later phase of the commitment period. These omissions precluded their ability to detect restoration of c-myc transcription, thereby causing them to overinterpret the contribution of the transcriptional component for c-myc regulation (Mechti et al. 1986).

The regulation of c-myc mRNA levels in MEL cells is complex. Although an increase in transcriptional block is responsible for the early decline in c-myc mRNAs, post-transcriptional mechanisms are operative during most of the differentiation program. Our inability to detect significant changes in the stability of c-myc mRNAs before and during HMBA treatment suggests that the post-transcriptional mechanisms that regulate the large changes in c-myc mRNA levels in differentiating MEL cells are probably nuclear in origin.

\section{Methods}

\section{Cell culture and transfection protocol}

MEL cells (line DS19) were maintained in Dulbecco's modified eagle's medium (DMEM) supplemented with $10 \%$ fetal bovine serum. For RNA extraction and the harvesting of nuclei, cells were kept in logarithmic growth for 2 days prior to induction by seeding the cells at $1-2 \times 10^{5} / \mathrm{ml}$ on days -2 and -1 . On day zero, the cells were seeded at $1-2 \times 10^{5} / \mathrm{ml}$ and treated with 5 mM hexamethylene bisacetamide (HMBA). An uninduced control sample was removed prior to the addition of HMBA.

An aliquot of cells from each experiment was maintained in
HMBA for 4 days and assayed for hemoglobin by benzidine reagent (Lachman and Skoultchi 1984). The percentage of benzidine-positive cells after 4 days in HMBA was routinely greater than $95 \%$. In the absence of HMBA, less than $1 \%$ of cells are benzidine positive.

\section{Nuclear run-on transcription}

Nuclei were purified and nascent transcripts were elongated for $30 \mathrm{~min}$, essentially as described by Schibler et al., without pretreatment of the nuclei with ribonuclease (Schibler et al. 1983; Nepveu and Marcu 1986). After elongation in vitro, the reaction was stopped by the addition of $10 \mu \mathrm{g}$ of RNase-free DNase from $\mathrm{BRL}$ and incubated at $27^{\circ} \mathrm{C}$ until the mixture was not viscous. An equal volume of $2 \times$ proteinase buffer [2 $\times$ : $20 \mathrm{~mm}$ Tris$\mathrm{NaCl}$ (pH 7.9), $20 \mathrm{~mm}$ EDTA, 1\% SDS] was added and proteinase $\mathrm{K}$ was added to a concentration of $200 \mu \mathrm{g} / \mathrm{ml}$. After incubation for $1 \mathrm{hr}$ at $42^{\circ} \mathrm{C}$, the solution was extracted twice with a mixture of phenol and chloroform. The solution was divided in two halves and the unincorporated nucleotides were removed by centrifugation through a Sephadex G-50 spin column. The eluates were pooled and mixed with an equal volume of $10 \%$ TCA, $60 \mathrm{mM} \mathrm{Na} \mathrm{P}_{2} \mathrm{O}_{7}$ in a microcentrifuge tube. After $30 \mathrm{~min}$ on ice, the solution was centrifuged for 15 min. The RNA pellet was resuspended in $250 \mu \mathrm{l}$ of $20 \mathrm{mM}$ HEPES ( $\mathrm{pH} 7.5$ ), $5 \mathrm{~mm}$ EDTA; $63 \mu \mathrm{l}$ of $1 \mathrm{~N} \mathrm{NaOH}$ was added, and the tubes were then vortexed and incubated for $15 \mathrm{~min}$ at $0^{\circ} \mathrm{C}$. Sizes of in vitro-synthesized nuclear RNAs were found to be 150-250 nucleotides under these conditions. Reactions were terminated by adding $125 \mu \mathrm{l}$ of $1 \mathrm{M}$ HEPES (free acid) and $50 \mu \mathrm{l}$ of $3 \mathrm{M}$ sodium acetate. The RNA was ethanol-precipitated, washed once in $70 \%$ ethanol, and resuspended in $1.5 \mathrm{ml}$ of hybridization buffer. The prehybridization and hybridization procedures are detailed elsewhere (Nepveu and Marcu 1987).

\section{RNA isolation and analysis}

Total cellular RNA was isolated by the hot phenol technique of Soeiro and Darnell (Soeiro and Darnell 1969). Northern filter hybridizations were performed according to Thomas (Thomas 1980). RNA blots were probed with a $\alpha$-32P-labeled Xho fragment containing the coding exons of the mouse c-myc cDNA clone pMc-myc54 (Stanton et al. 1983, 1984) or the mouse H3 histone plasmid pRAH3-2 (Alterman et al. 1984). Probes were labeled with an Amersham nick-translation kit and $\left[\alpha^{-32} \mathrm{P}\right]$ dCTP ( $3000 \mathrm{mCi} / \mathrm{mmole})$. The conditions for hybridization and filter washes were described previously (Lachman and Skoultchi 1984; Lachman et al. 1986).

S1 nuclease analysis was performed as described in our earlier publications (Stanton et al. 1983; Yang et al. 1985).

\section{Acknowledgments}

We thank Edvins Krecko for technical assistance and Barbara Springhorn, Chris Helmke, and Joyce Schirmer for manuscript and figure preparation. This work was supported by National Institutes of Health, grant PHS CA16368 and ACS grant CD-250 (awarded to A.I.S.) and National Institutes of Health grants CA4324601 (awarded to H.M.L.) and CA36246 lawarded to K.B.M.J. H.M.L. is a fellow of the John A. Hartford Foundation; A.N. is a fellow of the F.R.S.Q. of Quebec, Canada; and K.B.M. is a Catacosinos Cancer Research Professor.

\section{References}

Alterman, R.B., S. Ganguly, D. Schulze, W. Marzluff, C. 
Schildkraut, and A. Skoultchi. 1984. Cell cycle regulation of mouse $\mathrm{H} 3$ histone mRNA metabolism. Mol. Cell. Biol. 4: $123-132$.

Bentley, D.L. and M. Groudine. 1986. A block to elongation is largely responsible for decreased transcription of $c-m y c$ in differentiated HL60 cells. Nature 321: 702-706.

Coppola, J. and M. Cole. 1986. Constitutive c-myc expression blocks mouse erythroleukemia cell differentiation but not commitment. Nature 320: 760- 763.

Dani, C., J.M. Blanchard, M. Piechaczyk, S. El-Sabouty, L. Marty, and P. Jeanteur. 1984. Extreme instability of myc RNA in normal and transformed human cells. Proc. Natl. Acad. Sci. 81: 7046-7050.

Dani, C., N. Mechti, M. Piechacyzk, B. Lebleu, P. Jeanteur, and J.M. Blanchard. 1985. Increased rate of degradation of c-myc mRNA in interferon treated Daudi cells. Proc. Natl. Acad. Sci. 82: 4896-4899.

Dean, M., R.A. Levine, and J. Campisi. 1986. c-myc regulation during retinoic acid induced differentiation of F9 cells is post-transcriptional and associated with growth arrest. Mol. Cell. Biol. 6: 518-524.

Dmitrovsky, E., W.M. Keuhl, G.F. Hollis, I.R. Kirsch, J.P. Bender, and S. Segal. 1986. Expression of a transfected human c-myc oncogene inhibits differentiation of a mouse erythroleukemia cell line. Nature 322: 748-750.

Dony, C., M. Kessel, and P. Gruss. 1985. Post-transcriptional control of myc and P53 expression during differentiation of the embryonal carcinoma cell line F9. Nature 317: 636-639.

Eick, D. and G.W. Bornkamm. 1986. Transcriptional arrest within the first exon is a fast control mechanism in c-myc gene expression. Nucleic Acids Res. 14: 8331-8346.

Gusella, J., R. Geller, B. Clarke, V. Weeks, and D. Housman. 1976. Commitment to erythroid differentiation by Friend erythroleukemia cells: A stochastic analysis. Cell 9: 221229.

Lachman, H. and A.I. Skoultchi. 1984. Expression of c-myc changes during differentiation of mouse erythroleukemia cells. Nature 310: 592-594.

Lachman, H., G.H. Cheng, and A. Skoultchi. 1986. Transfection of mouse erythroleukemia cells with myc sequences changes the rate of induced commitment to differentiate. Proc. Natl. Acad. Sci. 83: 6480-6484.

Levine, R.A., J.E. McCormack, A. Buckler, and G.E. Sonenshein. 1986. Transcriptional and post-transcriptional control of c-myc gene expression in MEHI231 cells. Mol. Cell. Biol. 6: 4112-4116.

Marcu, K.B. 1987. Regulation of expression of the c-myc protooncogene. Bioessays 6: 28-32.

Marks, P.A. and R.A. Rifkind. 1978. Erythroleukemic differentiation. Annu. Rev. Biochem. 47: 419-448.

Mechti, N., M. Piechaczyk, J.M. Blanchard, L. Marty, A. Bonnieu, P. Jeanteur, and B. Lebleu. 1986. Transcriptional and post-transcriptional regulation of $c-m y c$ expression during the differentiation of murine erythroleukemia Friend cells. Nucleic Acids Res. 14: 9653-9665.

Nepveu, A. and K.B. Marcu. 1986. Intragenic pausing and antisense transcription within the murine c-myc locus. $E M B O J$. 5: 2859-2865.

Nepveu, A., R.A. Levine, J. Campisi, M.E. Greenberg, E.B. Ziff, and K.B. Marcu. 1987. Alternative modes of c-myc regulation in growth factor-stimulated and differentiating cells. Oncogene 1: 243-250.

Piechaczyk, M., J.M. Blanchard, L. Marty, C. Dani, F. Panatieres, S. El-Sabouty, P. Fort, and P. Jeanteur. 1984. Posttranscriptional regulation of glyceraldehyde-3-phosphate dehydrogenase gene expression in rat tissues. Nucleic Acids Res. 12: 6951-6963.
Piechaczyk, M., J.-Q. Yang, J.M. Blanchard, P. Jeanteur, and K.B. Marcu. 1985. Post-transcriptional mechanisms are responsible for accumulation of truncated c-myc mRNAs in murine plasma cell tumors. Cell 42: 589-597.

Prochownik, E.J. and J. Kukowska. 1986. Deregulated expression of c-myc by murine erythroleukaemia cells prevents differentiation. Nature 322: 848-850.

Ramsey, R.G., K. Ikeda, R. Rifkind, and P. Marks. 1986. Changes in gene expression associated with induced differentiation of erythrolekemia: Proto-oncogenes, globin genes, and cell division. Proc. Natl. Acad. Sci. 83: 6849-6853.

Ray, D., P. Meneceur, A. Tavitian, and J. Robert-Lezenes. 1987. Presence of a c-myc transcript initiated in intron 1 in Friend erythroleukemia cells and in other murine cell types with no evidence of c-myc gene rearrangement. Mol. Cell. Biol. 7: 940-945.

Reuben, R.C., R.L. Wife, R. Breslow, R.A. Rifkind, and P.A. Marks. 1976. A new group of potent inducers of differentiation in murine erythroleukemia cells. Proc. Natl. Acad. Sci. 73: $862-866$.

Schibler, W., O. Hagenbuchle, P.K. Wellauer, and A.C. Pittet. 1983. Two promoters of different strengths control the transcription of the mouse alpha-amylase gene Amy-1a in the parotid gland and the liver. Cell 33: 501-508.

Soeiro, R. and J.E. Darnell. 1969. Competition hybridization by pre-saturation of HeLa cell DNA. J. Mol. Biol. 44: 551-562.

Stanton, L.W., P.D. Fahrlander, D.M. Tesser, and K.B. Marcu. 1984. Nucleotide sequence comparison of normal and translocated murine c-myc genes. Nature 310: 423-425.

Stanton, L.W., R. Watt, and K.B. Marcu. 1983. Translocation, breakage and truncated transcripts of c-myc oncogene in murine plasmacytomas. Nature 303: 401-406.

Thomas, P.S. 1980. Hybridization of denatured RNA and small DNA fragments transferred to nitrocellulose. Proc. Natl. Acad. Sci. 77: 5201-5205.

Yang, J.Q., S.R. Bauer, J.F. Mushinski, and K.B. Marcu. 1985. Chromosome translocations clustered $5^{\prime}$ of the murine c-myc gene qualitatively effect promoter usage: Implications for the site of normal c-myc regulation. EMBO $/$. 4: 1441-1447. 


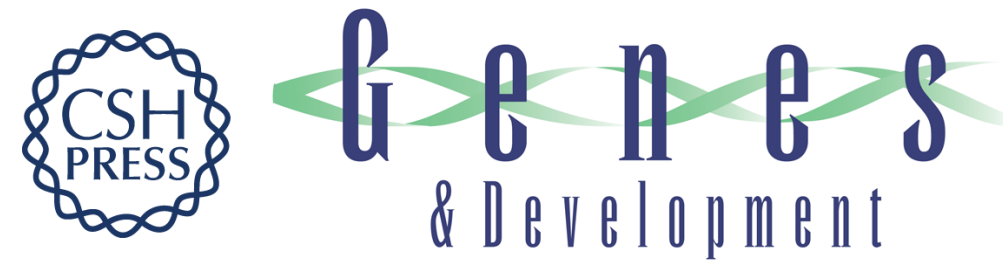

\section{Contributions of transcriptional and post-transcriptional mechanisms to the regulation of c-myc expression in mouse erythroleukemia cells.}

A Nepveu, K B Marcu, A I Skoultchi, et al.

Genes Dev. 1987, 1:

Access the most recent version at doi:10.1101/gad.1.9.938

References This article cites 30 articles, 10 of which can be accessed free at:

http://genesdev.cshlp.org/content/1/9/938.full.html\#ref-list-1

License

Email Alerting Receive free email alerts when new articles cite this article - sign up in the box at the top Service right corner of the article or click here.

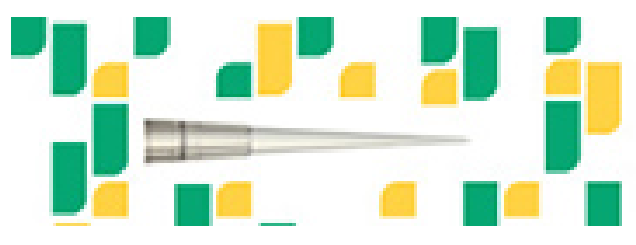

Focused on your science. 